\title{
Country-level correlates of cervical cancer mortality in Latin America and the Caribbean
}

\author{
Ana Pereira-Scalabrino, MD, PhD, (1) Maribel Almonte, $\mathrm{PhD}$, (2) Isabel dos-Santos-Silva, MD,PhD.(3)
}

\section{Pereira-Scalabrino A, Almonte M, dos-Santos-Silva I. Country-level correlates of cervical cancer mortality in Latin America and the Caribbean. Salud Publica Mex 20I3;55:5-I5.}

\begin{abstract}
Objective. To identify country-level correlates of geographical variations in cervical cancer (CC) mortality in Latin America and the Caribbean (LAC). Materials and methods. CC mortality rates for LAC countries $(n=26)$ were examined in relation to country-specific socio-economic indicators $(n=58)$ and Human Papilloma Virus (HPV) prevalence using linear regression models. Results. High mortality at ages $<5$ years, low per capita total expenditure on health, and low proportion of the population with access to sanitation were identified as the best independent predictors of CC mortality $\left(R^{2}=77 \%\right)$. In the subset of countries $(n=10)$ with HPV prevalence estimates, these socio-economic indicators together with high-risk HPV prevalence explained almost all the between-country variability in CC mortality $\left(R^{2}=98 \%\right)$. Conclusion. The findings suggest that continuing socioeconomic improvements in LAC countries will be associated with further reductions in CC mortality even in the absence of organised population-based screening and vaccination programmes.
\end{abstract}

Keywords: uterine cervical neoplasms; papillomaviridae; mass screening; Latin America
Pereira-Scalabrino A, Almonte M, dos-Santos-Silva I. Determinantes a nivel país de la mortalidad por cáncer cervicouterino en Latinoamérica y el Caribe.

Salud Publica Mex 20I3;55:5-I5.

\section{Resumen}

Objetivo. Identificar variables a nivel de país que expliquen las variaciones geográficas en la mortalidad por cáncer cervicouterino ( $\mathrm{CaCu}$ ) en América Latina y el Caribe $(\mathrm{AL})$. Materiales y métodos. Se examinaron las tasas de mortalidad por $\mathrm{CaCu}$ de cada país $(\mathrm{n}=26)$ mediante modelos de regresión lineal en relación con indicadores socioeconómicos $(n=58)$ y prevalencia del virus del papiloma humano (VPH). Resultados. Alta mortalidad en menores de cinco años, bajo gasto total en salud per-cápita y baja proporción de población con acceso a saneamiento básico son los mejores predictores de mortalidad por $\mathrm{CaCu}\left(\mathrm{R}^{2}=77 \%\right)$. En los países $(n=10)$ con estimaciones de prevalencia de VPH, estos indicadores socioeconómicos y la prevalencia de VPH de alto riesgo explicaron el $98 \%$ de la variabilidad de $\mathrm{CaCu}$ en AL. Conclusión. Las mejoras en el nivel socioeconómico en $\mathrm{AL}$ están asociadas con reducciones en la mortalidad por $\mathrm{CaCu}$, a pesar de la ausencia de programas organizados de tamizaje e inmunización contra VPH.

Palabras clave: neoplasias del cuello uterino; papillomaviridae humano; tamizaje masivo; América Latina

(I) Unidad de Epidemiología Nutricional y Genética, Instituto de Nutrición y Tecnología de los Alimentos, Universidad de Chile. Santiago, Chile.

(2) Cochrane Institute of Primary Care and Public Health, Cardiff University. Wales, UK.

(3) Department of Non-Communicable Disease Epidemiology, London School of Hygiene and Tropical Medicine. England. 
$\mathrm{C}$ ervical cancer (CC) is the second most common female non-skin cancer in the world. According to Globocan $2008,{ }^{1} 13 \%$ of all CC cases and $11 \%$ of all CC deaths worldwide occur in Latin America and the Caribbean (LAC), with rates being higher than in more developed countries. There is, however, marked between-country variability in CC rates in LAC with a four to five-fold difference in rates between high (e.g. Nicaragua and Guyana) and low risk countries (e.g. Uruguay and Chile) ${ }^{1,2}$ Persistent infection with highrisk Human Papillomavirus (HPV) is a necessary cause for CC development, ${ }^{3}$ but geographical variations in the prevalence of HPV do not seem to fully explain the variability in CC rates worldwide. ${ }^{4}$ Organised cervical screening programmes based on cytology can reduce CC incidence and mortality rates ${ }^{5}$ by as much as 80 $90 \% .{ }^{6}$ Both ecological and individual-based studies have shown that markers of socio-economic (SE) status, such as educational level, are related to CC incidence and mortality, with women with low SE status being at higher risk of developing, or dying from, this cancer. ${ }^{7,8}$

We conducted an ecological study to assess the extent to which between-country differences in CC mortality in LAC are accounted by level of SE development, HPV prevalence and screening activity.

\section{Materials and methods}

\section{CC mortality rates}

Country-specific CC mortality rates (age-adjusted to the World standard population) for 2008 were extracted from GLOBOCAN 2008. ${ }^{1}$ These rates were estimated from death certification data provided by each country to the World Health Organization (WHO) except for Bolivia, Guyana, Honduras, Jamaica and Haiti. For these countries, CC mortality estimates were corrected for under-reporting (Guyana), or derived using data on CC incidence rates and survival (Bolivia) or CC mortality from neighbouring countries (Honduras, Jamaica). ${ }^{1}$ Haiti was excluded from the analysis because its GLOBOCAN estimates were markedly different for 2002 and 2008 (i.e. age-adjusted rates of 48 and 10 per 100000 women, respectively). ${ }^{1,9}$

\section{Level of SE development}

Data on demographic, SE and public health indicators for the years 2000-2005 were extracted, for each LAC country, from official web pages or reports published by non-governmental organisations, including the $\mathrm{WHO},{ }^{10}$ the Pan-American Health Organisation (PAHO), ${ }^{11-13}$ the United Nations Statistics Division ${ }^{14}$ and Human Development Report. ${ }^{15}$ These indicators were categorised into nine strata (table I): demographic (eight indicators), mortality (eight), morbidity (two), immunisation coverage (five), tobacco use (two), sexual and reproductive behaviour (six), health services (ten), economic (eleven) and development (six) indicators. Linear univariate regression models, weighted by size of the female population in each country, were fitted to examine the association between each one of these 58 indicators and CC mortality at a country level. For each one of the nine strata described above, the indicator with the highest $R^{2}$, a $p$-value $<0.05$ and available data for all LAC countries examined was chosen to be included in a multiple regression model. The tobacco use stratum was excluded because none of its indicators had information for all the countries examined (table I). The correlation between the remaining eight selected stratum-specific indicators was then evaluated and whenever two of these were strongly correlated $(r>0.80)$, the one with the larger $p$-value and/or smaller $R^{2}$ was replaced by the next indicator in the same stratum that most closely fulfilled the above criteria. This process was repeated until none of the eight stratum-specific indicators were strongly correlated with each other $(\mathrm{r}<0.80)$. A multiple linear regression model was then fitted to the final selection of stratum-specific indicators, and the log-likelihood ratio test used to identify the best independent predictors of CC mortality.

A composite risk score was generated on the basis of the identified predictors. Firstly, the 26 LAC countries were ranked separately according to the values of each one of the identified predictors and a predictor-specific risk score assigned to each country to reflect this ranking (e.g. for a predictor positively associated with CC mortality a score of 1 was assigned to the country with the lowest predictor value and a score of 26 to the country with the highest; for a predictor inversely associated with CC mortality a score of 1 was assigned to the country with the highest predictor value and a score of 26 to the country with the lowest). A composite risk score for each country was then calculated as the sum of its predictor-specific risk scores (i.e. for 3 predictors, country-specific composite scores could range from 3 to 78 depending on the direction of their association with CC mortality).

\section{HPV prevalence}

Data on country-specific HPV prevalence estimates, any genotype and high-risk genotypes (HPV16 and HPV18), and the women's ages at the time of HPV assessment, were extracted from the $\mathrm{WHO} / \mathrm{ICO}$ Information Centre on HPV and CC. ${ }^{16}$ Its website presents worldwide data 
Table I

\section{Country-leVel demographic, SOCIOECONOMIC AND PUblic HeALTH CORRELATES, IN 2000-2005, Of CERVICAL CANCER mortality in Latin America and the Caribbean IsLands (LAC)}

Type of Indicator

Indicator (no. of countries for which data were available) / [reference]

Demographical characteristics

\begin{tabular}{|c|c|c|c|c|c|}
\hline Urban population $(\%)(26) /{ }^{\prime \prime}$ & 63.60 & $57.80-77.40$ & -0.18 & 0.4 & 0.001 \\
\hline Proportion of population aged less than I5 years (\%) (26)/II & 28.94 & $25.90-31.61$ & 0.57 & 0.47 & $<0.001$ \\
\hline Proportion of population aged 60 years and over (\%) $(26) /^{\prime \prime}$ & 8.04 & $6.71-10.20$ & -0.83 & 0.37 & 0.001 \\
\hline Dependency ratio [Dependent population per 100 productive population] $(26) /{ }^{\prime \prime}$ & 57.55 & $52.70-64.80$ & 0.22 & 0.34 & 0.002 \\
\hline Annual rate of population growth $(\%)(26) /{ }^{\prime \prime}$ & 1.40 & $0.70-1.70$ & 5.41 & 0.41 & $<0.001$ \\
\hline Crude birth rate (per I 000 population) (26)/II & 20.75 & $18.30-23.90$ & 0.64 & 0.54 & $<0.001$ \\
\hline$\%$ of the population of Native origin $(26) /^{10}$ & 4.00 & $2.00-14.00$ & 0.08 & 0.22 & 0.015 \\
\hline$\%$ of the population of Afro American origin (I5)(a)/10 & 9.00 & $2.00-21.00$ & -0.02 & 0.03 & 0.53 \\
\hline
\end{tabular}

$\begin{array}{ccccc} & \text { Percentil } & B & R^{2} \quad P\end{array}$

$25 \%-75 \%$

Public health indicators

Mortality

Female life expectancy at birth (in years) $(26) /^{10}$

Female healthy life expectancy at birth (in years) $(26) /^{10}$

$\begin{array}{lllll}74.00 & 71.00-78.00 & -0.75 & 0.48 & <0.001\end{array}$

Infant mortality rate (per I 000) (26)/ ${ }^{10}$

$\begin{array}{lllll}64.20 & 62.20-68.00 & -0.6 & 0.38 & 0.001\end{array}$

Neonatal mortality rate (per I 000) $(26) / 10$

$\begin{array}{lllll}22.00 & 16.00-31.00 & 0.14 & 0.16 & 0.046\end{array}$

Maternal mortality ratio (per 100000$)(26) / 10$

$\begin{array}{lllll}15.00 & 10.00-18.00 & 0.52 & 0.35 & 0.001\end{array}$

Age-standardized cancer (all sites combined)mortality rate (per 100000$)(26) /^{10}$

$\begin{array}{lllll}120 & 78.00-170.00 & 0.01 & 0.23 & 0.013\end{array}$

Percentage of years of life lost to non-communicable diseases (\%) (26)/ $/ 10$

$\begin{array}{lllll}130.30 & 112.20-141.80 & 0.03 & 0.06 & 0.217\end{array}$

Estimated mortality under 5 years of age (per I 000) $(26) /^{10}$

$\begin{array}{lllll}44.55 & 36.50-56.80 & -0.2 & 0.43 & <0.001\end{array}$

Morbidity

Crude annual incidence of tuberculosis ( 100000 population) $(26) /^{10}$

$\begin{array}{lllll}28.80 & 16.70-43.60 & 0.2 & 0.57 & <0.001\end{array}$

Prevalence of low birth weight [\%] (26)/10

$\begin{array}{lllll}66.85 & 32.80-106.80 & 0.04 & 0.38 & <0.001\end{array}$

Immunization Coverage

Proportion of one-year-olds immunized with one dose of measles (\%) (26)/10 $\quad 92.00 \quad 86.00-95.00 \quad-0.23 \quad 0.31 \quad 0.003$

Proportion of one-year-olds immunized with three doses of diphtheria

tetanus toxoid and pertussis (DTP3) (\%) (26)/10

$90.00 \quad 85.00-94.00 \quad-0.29 \quad 0.31 \quad 0.003$

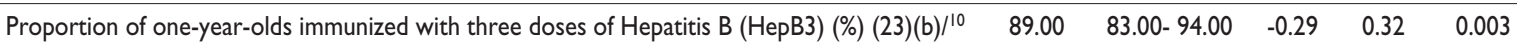

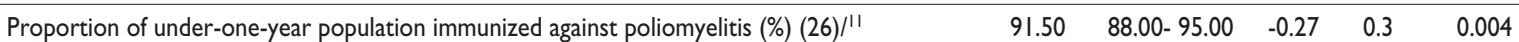

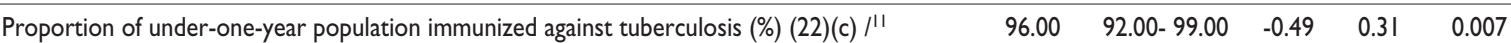

Tobacco Use

Prevalence of current tobacco smoking among adult women (\%) (9)(d)/10

$13.20 \quad 7.00-17.50 \quad-0.28 \quad 0.61 \quad 0.012$

Prevalence of tobacco smoking among adolescents aged I2-18 years (\%) (25)(e)/ ${ }^{1}$

$20.50 \quad|8.30-25.40 \quad-0.3| \quad 0.25 \quad 0.01$

Sexual and reproductive behaviour

\begin{tabular}{|c|c|c|c|c|c|}
\hline Total fertility rate $(26) /^{\prime \prime}$ & 2.50 & $2.20-2.80$ & 4.69 & 0.49 & $<0.001$ \\
\hline Specific fertility rate in women aged I5-19 years (per I 000 population) (26)/ I & 74.60 & $58.50-85.20$ & 0.08 & 0.14 & 0.055 \\
\hline Percentage of women who gave birth between I5-19 years $(26) / 13$ & 7.00 & $5.00-9.00$ & 0.58 & 0.09 & 0.094 \\
\hline Prevalence of use of any contraceptive methods among women (\%) $(26) /^{\prime \prime}$ & 59.40 & $46.30-69.00$ & -0.04 & 0.04 & 0.315 \\
\hline Use of oral contraceptives among women $(2 \mathrm{I})(\mathrm{f}) /^{12}$ & 11.80 & $7.10-20.70$ & -0.47 & 0.37 & 0.003 \\
\hline Age of first intercourse among women $(\mathrm{II})(\mathrm{g}) /^{/ 2}$ & 19.00 & $18.55-19.20$ & -1.04 & 0.17 & 0.186 \\
\hline
\end{tabular}


(Continue)

Health services indicators

\begin{tabular}{|c|c|c|c|c|c|}
\hline Number of physicians (per I 000 population) $(25)(\mathrm{h}) /{ }^{10}$ & 1.21 & $1.05-1.50$ & -1.37 & 0.17 & 0.04 \\
\hline Number of nurses (per I 000 population)(25) (i)/10 & 1.57 & $0.90-2.87$ & 0.1 & 0 & 0.797 \\
\hline Number of outpatient care facilities $(26) /^{\prime \prime}$ & 1818.0 & $367.00-5835.0$ & -0.001 & 0.11 & 0.106 \\
\hline Hospital beds ratio (per I 000 population) (26)/"I I & 1.60 & $1.00-2.90$ & -1.31 & 0.22 & 0.016 \\
\hline Outpatient health care visits ratio (per I 000 population) $(25)(\mathrm{j}) / I I$ & 1774.3 & 1070.70- 2502.3 & -0.001 & 0.07 & 0.188 \\
\hline Hospital discharges ratio (per I 000 population) (26)/"I & 63.45 & $54.20-80.00$ & -0.03 & 0.07 & 0.202 \\
\hline Proportion of pregnant women followed by trained personnel during pregnancy $(\%)(26) /^{\prime \prime}$ & 88.10 & 79.00-94.00 & -0.02 & 0.02 & 0.443 \\
\hline Proportion of deliveries attended by trained personnel (\%) $(26) /^{\prime \prime}$ & 94.25 & $83.70-99.10$ & -0.16 & 0.41 & $<0.001$ \\
\hline Coverage of death registrations $(\%)(22)(\mathrm{k}) / 10$ & 87.05 & 73.80- 97.00 & -0.13 & 0.43 & 0.001 \\
\hline Proportion of certified deaths due to ill-defined and unknown conditions $(\%)(25)(\mathrm{h}) /^{\prime l}$ & 6.40 & $2.40-12.50$ & 0.15 & 0.14 & 0.06 \\
\hline
\end{tabular}

Economic statistics

Total expenditure on health as percentage of $\operatorname{GDP}(26) / 10$

\begin{tabular}{rcccr}
6.95 & $5.30-7.60$ & -1.1 & 0.2 & 0.022 \\
\hline 48.35 & $44.30-64.00$ & -0.04 & 0.02 & 0.449 \\
\hline 322.00 & $233.00-597.00$ & -0.01 & 0.64 & $<0.001$ \\
\hline 187.50 & $109.00-345.00$ & -0.02 & 0.61 & $<0.001$ \\
\hline 6779.2 & $4018.7-9109.5$ & -0.001 & 0.76 & $<0.001$ \\
\hline 2.50 & $1.30-3.90$ & -0.25 & 0.09 & 0.157 \\
\hline 11.48 & $6.61-22.79$ & -0.12 & 0.14 & 0.075 \\
\hline 18.00 & $11.00-21.50$ & -0.11 & 0.03 & 0.439 \\
\hline 8.20 & $3.00-16.40$ & 0.39 & 0.62 & $<0.001$ \\
35.00 & $21.80-49.00$ & 0.09 & 0.21 & 0.058 \\
\hline 9.85 & $6.40-14.00$ & -0.05 & 0.01 & 0.665
\end{tabular}

Development

Proportion of the population with sustainable access to an improved water

\begin{tabular}{|c|c|c|c|c|c|}
\hline source $(\%)(26) /^{11}$ & 91.00 & $85.00-94.00$ & -0.59 & 0.54 & $<0.001$ \\
\hline Proportion of the population with access to improved sanitation (\%) (26)/II & 76.00 & $66.00-92.00$ & -0.25 & 0.57 & $<0.001$ \\
\hline Female literacy rate $(\%)(26) /^{13}$ & 92.50 & $87.20-96.60$ & -0.32 & 0.42 & $<0.001$ \\
\hline Average number of years of formal education for the total population $(25)(\mathrm{q})^{/ 14}$ & 13.00 & $12.00-14.00$ & -1.03 & 0.16 & 0.048 \\
\hline Average number of years of formal education for the female population $(22)(r) /^{14}$ & 13.00 & $12.00 \mid 4.00$ & -1.16 & 0.27 & 0.014 \\
\hline Human Development Index*, 2004 (26)/15 & 0.78 & $0.73-0.83$ & -64.38 & 0.77 & $<0.001$ \\
\hline
\end{tabular}

GDP: Growth Domestic Product, PPP: Purchasing power parity

* Human Development Index: is a composite statistic used to rank countries by level of "human development" which takes into account life expectancy, literacy, level of education and standards of living

(a) excluded: Argentina, Bahamas, Barbados, Belize, Chile, El Salvador, Guatemala, Guyana, Jamaica, Suriname, Trinidad and Tobago

(b) excluded: Chile, Guatemala, Suriname

(c) excluded: Bahamas, Barbados, Suriname \& Trinidad \& Tobago

(d) included: Brazil, Chile, Dominican Republic, Ecuador, Guatemala, Honduras, Mexico, Paraguay, Uruguay,

(e) excluded: Dominican Republic

(f) excluded: Argentina, Chile, Panama, Uruguay, Venezuela

(g) excluded: Argentina, Barbados, Belize, Bolivia, Brazil, Chile, Colombia, Cuba, Guayana, Mexico, Panama, Suriname, Trinidad and Tobago, Uruguay, Venezuela

(h) excluded: Honduras

(i) excluded: Venezuela

(j) excluded: Colombia

(k) excluded: Bolivia, Honduras, Jamaica, Suriname

(l) excluded: Cuba, Suriname

(m) excluded: Cuba

(n) excluded: Barbados, Belize, Cuba, Suriname

(o) excluded: Barbados,Belize, Bolivia, Cuba, Suriname

(p) excluded: Mexico, Uruguay, Venezuela, Barbados, Belize, Bolivia, Cuba, Suriname

(q) excluded: Ecuador

(r) excluded: Bolivia, Costa Rica, Ecuador, Guyana 
on HPV prevalence ${ }^{4,17}$ compiled through systematic reviews of the literature published between 1995 and 2009; publications were eligible if HPV assessment was based on polymerase chain reaction (PCR) or Hybrid Capture2 (HC2), and the sample included $>90$ women with normal cytological findings. Age-specific HPV prevalence estimates were available from the $\mathrm{WHO} /$ ICO website for 10 LAC countries (Argentina, Brazil, Chile, Colombia, Costa Rica, Guatemala, Honduras, Mexico, Paraguay and Peru). Regression models, restricted to these 10 countries, were fitted to examine the association between HPV prevalence (any and high-risk HPV) and CC mortality, adjusting for age at HPV ascertainment and also additionally for the SE predictors identified by the analysis described above.

\section{Cervical screening}

Information on screening policies and their level of implementation, including Pap smear coverage estimates from nationally representative surveys and other sources, were extracted from a previously published source ${ }^{18}$ and updated using the same methodology as previously. Information was also gathered on the use of HPV detection methods and on HPV vaccination policies.

Analyses were conducted in Stata v.10. The study was carried out at the London School of Hygiene and Tropical Medicine. Ethical approval was not required because only publicly-available secondary data were analysed.

\section{Results}

There were marked between-country differences for most demographic, SE and public health indicators (table I). For instance, there was a 9.5-fold difference between the countries with the highest (Bolivia) and the lowest (Chile) mortality rate among children aged under 5 years, and a 7-fold difference between the countries with the highest (Bahamas) and the lowest (Bolivia) per-capita expenditure on health.

The univariate analyses showed that countries with the highest $\mathrm{CC}$ mortality rates tended to be those with the youngest age-structure, lowest degree of urbanisation, lowest SE development and poorest health indicators (table I). Crude birth rate, mortality rate under five years, incidence of tuberculosis, proportion of one-year-olds immunized with one dose of measles, total fertility rate, proportion of deliveries attended by trained personnel, per capita total expenditure on health, and proportion of the population with access to improved sanitation were the variables selected to represent each one of the eight strata of indicators in the multiple regression analysis.
Mortality rate under 5 years of age, per capita total expenditure on health and proportion of the population with access to improved sanitation were identified as the best independent predictors of CC mortality in LAC (table II), accounting for $77 \%$ of the between-country variability in rates. There was a positive linear association between the composite risk score and CC mortality at a country level (figure 1).

Stratifying LAC countries according to their CC mortality (table III) showed, as expected, that the highest CC mortality-stratum had, on average, the highest mortality rate at age under-5-years, the lowest mean per capita total expenditure on health, and the lowest proportion of the population with access to improved sanitation.

In analyses restricted to the subset of 10 countries with available HPV data, the three independent SE predictors identified above explained $90 \%$ of the betweencountry variability in CC mortality (table II) whereas age-adjusted prevalence of any HPV genotype, or of highrisk HPV genotypes, alone explained only 8-9\% (table II). The correlation between HPV and SE predictors was low $(\mathrm{r}<0.30)$. Nevertheless, the $\mathrm{R}^{2}$ increased to $98 \%$ when both SE predictors and high-risk HPV prevalence (to $97 \%$ if the latter was replaced by prevalence of any HPV genotype) were included in the same model (table II).

Cytology-based screening programmes were first introduced in LAC in the early 1960s (table IV). Most programmes are opportunistic. Only the Chilean national programme recommends a national call-recall system, ${ }^{19}$ but there is no evidence that such recommendation has been implemented. A few local organised screening programmes have been set up (e.g. certain regions of Brazil), ${ }^{20-22}$ but none has established a callrecall system. Different methodologies and age-groups were used to estimate Pap smear coverage, thus making between-country comparisons difficult. Estimates for Pap-smear coverage within 2-3 years prior to the survey (available for nine countries) ranged from 31 to $69 \%{ }^{20,23-31}$ Estimates of the proportion of women ever screened (available for seven countries) ranged from 35 to $85 \%, 25,29,32-35$ being greater than $80 \%$ (at ages 15-49) only in El Salvador. ${ }^{33}$ Those that report annual screening ranged from $22.7 \%$ to $44.8 \%{ }^{35-38}$ Screening relied mainly on cytology (Papanicolaou test), but in recent years visual inspection after the application of acetic acid (VIA) and HPV testing have also been incorporated into national screening policies (e.g. the latter is currently being used in primary screening in Mexico and in demonstration projects in Argentina, Colombia, and Peru). National HPV vaccination programmes, targeting girls aged 9-11 years, were initiated in 2008 in Mexico, Panama, Argentina and Peru. ${ }^{39-43}$ 
Table II

Multiple Regression analyses to IDENTIFY the best demographic, SOCIOECONOMIC AND PUBLIC HEALTH CORRELATES, IN 2000-2005, OF BETWEEN-COUNTRY DIFFERENCES IN CERVICAL CANCER MORTALITY, in 2008, in Latin America and the Caribbean IsLands

Correlates

$\beta^{*}$

$95 \% \mathrm{Cl}$

$P \quad R^{2}$

All LAC countries examined $(n=26)$

Model with SE variables only

Estimated mortality under 5 years old (per I 000) ${ }^{10}$

0.05

Per capita total expenditure on health $¥ 10$

$-0.01$

$-2.42$

$77 \%$

Proportion of population with access to improved sanitation (\%)"

Subset of LAC countries with available HPV prevalence data $(n=10)$

Model with any HPV prevalence only§

Prevalence of any HPV genotype ${ }^{16}$

Model with high-risk HPV prevalence only \$.\#

Prevalence of high-risk HPV genotypes ${ }^{16}$

del with SE variables only

0.17

$(-0.38,0.72)$

$8 \%$

Estimated mortality under 5 years old (per I 000) $)^{10}$

Per capita total expenditure on health ${ }^{\ddagger 10}$

Proportion of population with access to improved sanitation (\%)"

Model with SE variables and prevalence of any HPV genotype ${ }^{\S}$

Estimated mortality under 5 years old (per I 000) ${ }^{10}$

Per capita total expenditure on health ${ }^{\ddagger 10}$

Proportion of population with access to improved sanitation (\%)"

Prevalence of any HPV genotype ${ }^{16}$

Model with SE variables and prevalence of high-risk HPV genotypes ${ }^{\text {s.\# }}$

Estimated mortality under 5 years old (per I 000) $)^{10}$

Per capita total expenditure on health $\ddagger 10$

Proportion of population with access to improved sanitation (\%)"

Prevalence of high-risk HPV genotypes ${ }^{16}$

0.50

$(-0.93,1.93)$

$9 \%$

唡

HPV=Human Papillomavirus; SE=socioeconomic

* This coefficient represents the slope of the linear regression, which means the rate of change of CC mortality associated with a unit increase in the exposure variable

¥ At international dollar rate

$\S$ Adjusting for age at time of HPV ascertainment

\# HPVI6 and HPV 18

\section{Discussion}

This ecological study found that markers of level of SE development were inversely associated with CC mortality. Using data from 127 developing countries, Drain et $a l .{ }^{44}$ found that country-specific CC incidence rates were negatively associated with health indicators but, in contrast to our study, CC incidence was not inversely associated with most SE indicators; in fact, there was a positive relationship between health expenditure and CC incidence, which was attributed to China having both low health spending and low CC incidence.
Individual-based studies carried out in LAC have shown that CC mortality and incidence are associated with SE status. ${ }^{45}$ Women with a low SE status may have a more risky sexual behaviour, thus increasing their likelihood of acquiring a HPV infection, and an increased risk of HPV persistence and progression to pre-invasive lesions due, for instance, to higher smoking prevalence ${ }^{46}$ and higher parity. ${ }^{47}$ They are also more likely to have poor access to health services including early detection, diagnostic and treatment facilities. ${ }^{7,48}$

Improvements in the SE level of a country, even in the absence of a well-established screening programme, 

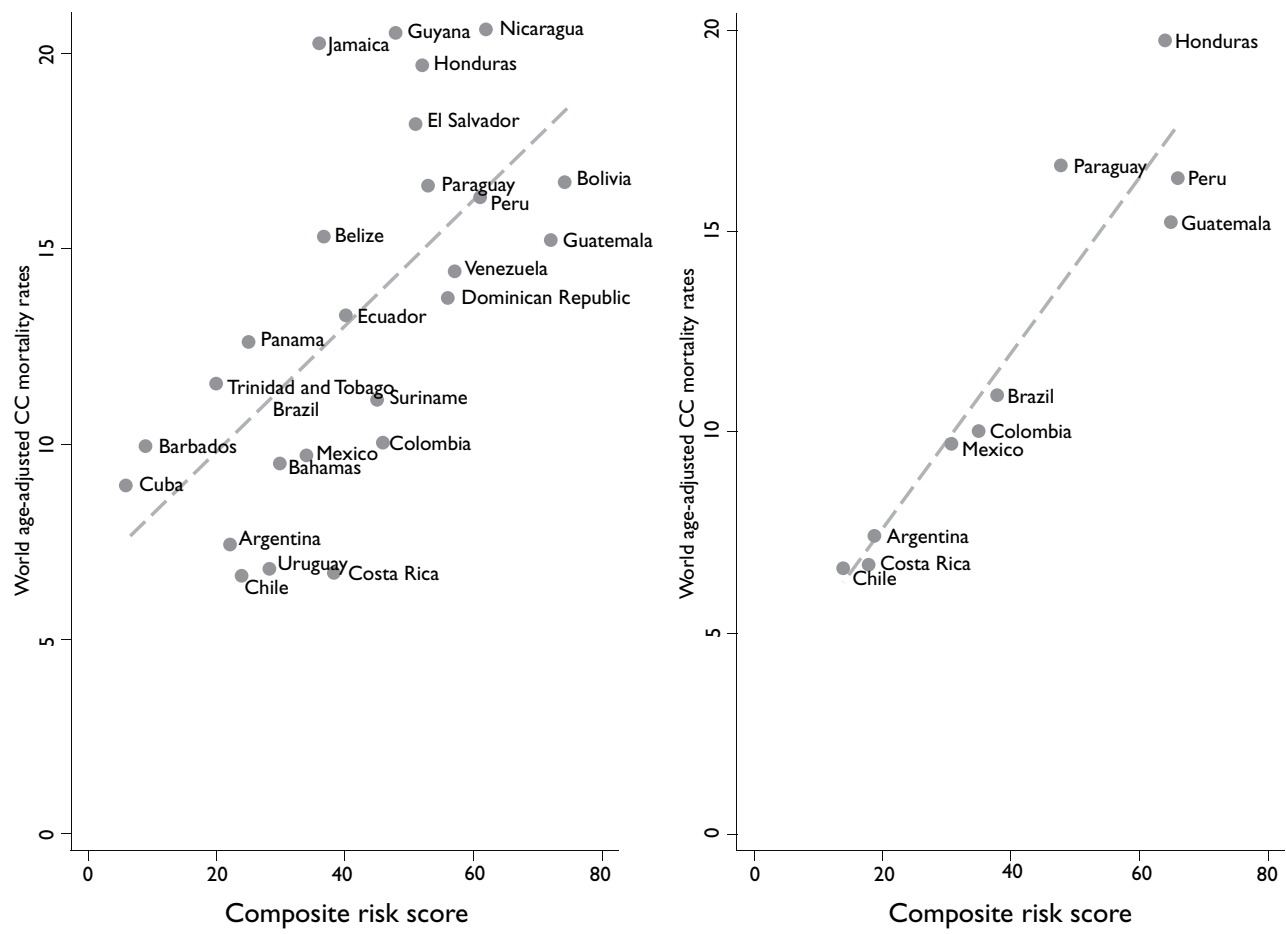

Figure I. Correlation between the composite risk score (see Methods and Results sections), 2000-2005, and ageADJUSTED CC MORTALITY RATES, IN 2008, IN LATIN AMERICA AND tHe CARIBBEAN IsLANDS (LAC): (A) ALL 26 LAC COUNTRIES EXAMINED (B) RESTRICTED to IO LAC COUNTRIES With AVAILABLE HPV PREVALENCE DATA. (THe DOTS CORRESPOND tO THE OBSERVED CC RATES AND THE LINE TO THOSE PREDICTED BY THE LINEAR REGRESSION MODEL)

may decrease CC mortality rates, ${ }^{49}$ perhaps to declines in HPV prevalence and increased access to early detection and treatment. ${ }^{50,51}$ Data from three population-based cancer registries in LAC (Cali in Colombia, Costa Rica and Ecuador) show a decline in CC incidence from 1970 to 1995 , a period when Pap smear coverage remained low but SE level improved. ${ }^{2}$

In the subset of 10 countries for which HPV prevalence estimates were available, high-risk HPV prevalence alone explained only $9 \%$ of the betweencountry variability in CC mortality whereas SE correlates explained $90 \%$. However, when both SE correlates and high-risk HPV prevalence were included in the same model, these variables explained practically all between-country variability in CC mortality $\left(R^{2}=98 \%\right)$. These findings suggest that $\mathrm{SE}$ indicators may be a better correlate of between-country differences in CC mortality than HPV prevalence; however, they may simply reflect the much better quality of the SE data.

The paucity of comparable data on Pap smear coverage precluded examination of the extent to which between-country differences in CC mortality reflected differences in screening activity. The available estimates indicate that coverage is likely to have been low in most countries. Previous studies revealed low cytology quality, poor follow-up and poor treatment compliance. ${ }^{52}$ A study carried out by RedPac, an initiative set up to monitor and improve Pap smear quality in LAC, showed that cytology quality was poor in many countries (e.g. percentage of false-negatives in 2000 was 27\% in Peru, $23 \%$ in Venezuela, and $<5 \%$ in Chile and Costa Rica). ${ }^{18,35}$ The effectiveness of screening was also affected by poor turnaround time, ${ }^{53}$ mainly in rural areas, ${ }^{54}$ with only $34 \%$ abnormal smears being appropriately followed-up in Peru, 59\% in Bolivia, and $>90 \%$ in Chile and Cuba. ${ }^{18}$ New screening methods (e.g. visual inspection after acetic acid [VIA] and HPV testing) are being adopted in certain LAC countries (table IV) but their introduction is far too recent to have had any major impact on the mortality rates examined here.

Our study is not exempt of limitations. Firstly, the analyses relied on mortality data, which reflects both 
Table III

THE BEST IDENTIFIED DEMOGRAPHIC, SOCIOECONOMIC AND PUBLIC HEALTH CORRELATES (AND CORRESPONDING COMPOSITE SCORES*), IN 2000-2005, OF BETWEEN-COUNTRY DIFFERENCES IN CERVICAL CANCER MORTALITY, IN 2008, in Latin America and the Caribbean IsLands

Country
(composite risk score)

Adjusted CC Mortality rate
Estimated mortality under 5 years old $($ per I 000) 10
Per capita total expenditure on health at international dollar rate ${ }^{10}$
Proportion of population with access to improved sanitation (\%)"

CC mortality less than 10 per 100000 women year

\begin{tabular}{|c|c|c|c|c|}
\hline Chile (I5) & 6.6 & 9.3 & 707 & 92 \\
\hline Costa Rica (I7) & 6.7 & 11.9 & 616 & 92 \\
\hline Uruguay (14) & 6.8 & 14.8 & 824 & 94 \\
\hline Argentina (19) & 7.4 & 16.7 & 1067 & 82 \\
\hline Cuba (23) & 8.9 & 7.1 & 251 & 98 \\
\hline Bahamas (8) & 9.5 & 15.3 & 1220 & 100 \\
\hline Mexico (3I) & 9.7 & 22.9 & 582 & 77 \\
\hline Barbados (9) & 9.9 & 11.6 & 1050 & 99 \\
\hline Mean (SD) & $8.2(1.5)$ & I $3.7(4.9)$ & $789.6(316.5)$ & $91.8(8.3)$ \\
\hline
\end{tabular}

CC mortality 10 to 16 per 100000 women year

\begin{tabular}{|c|c|c|c|c|}
\hline Colombia (35) & 10.0 & 30.9 & 522 & 86 \\
\hline Brazil (38) & 10.9 & 33.3 & 597 & 75 \\
\hline Suriname (34) & II.I & 29.4 & 309 & 93 \\
\hline Trinidad and Tobago (19) & 11.5 & 18.6 & 532 & 100 \\
\hline Panama (35) & 12.6 & 25.7 & 555 & 72 \\
\hline Ecuador (5I) & 13.3 & 28.2 & 220 & 72 \\
\hline Dominican Republic (59) & 13.7 & 47.7 & 335 & 57 \\
\hline Venezuela (5I) & 14.4 & 28.0 & 231 & 68 \\
\hline Guatemala (65) & 15.2 & 48.1 & 235 & 61 \\
\hline Belize (59) & 15.3 & 40.2 & 309 & 47 \\
\hline Mean (SD) & $12.8(1.9)$ & $33.0(9.6)$ & 384.5 (149.7) & $73.1(10.9)$ \\
\hline
\end{tabular}

CC mortality more than 16 per 100000 women year

\begin{tabular}{lllll} 
Peru (66) & 16.3 & 49.5 & 233 & 62 \\
\hline Paraguay (48) & 16.6 & 43.6 & 301 & 78 \\
\hline Bolivia (78) & 16.7 & 67.6 & 176 & 45 \\
\hline El Salvador (49) & 18.2 & 32.5 & 378 & 63 \\
\hline Honduras (65) & 19.7 & 46.3 & 184 & 68 \\
\hline Jamaica (43) & 20.3 & 20.3 & 216 & 80 \\
\hline Guyana (59) & 20.5 & 64.6 & 283 & 70 \\
\hline Nicaragua (62) & 20.6 & 38.0 & 208 & 66 \\
\hline Mean (SD) & $\mathbf{1 8 . 6 ( 1 . 9 )}$ & $\mathbf{4 5 . 3 ( 1 5 . 7 )}$ & $\mathbf{2 4 7 . 4 ( 6 8 . 7 )}$ & $\mathbf{6 6 . 5}(\mathbf{1 0 . 9 )}$
\end{tabular}

* country-specific score estimated as the sum of the ranking of the three predictors identified by the multiple regression analysis with a possible range from 3 to 78 (see Methods and Results sections)

incidence of, and survival from, CC. There are few population-based cancer registries in LAC and most are local. The quality of the mortality data was also far from ideal. The estimates produced by GLOBOCAN (IARC/ WHO) took into account under-registration of death and percentage of registered deaths coded as "ill-defined" conditions, but different methods were used to estimate rates for each country depending on data availability. Secondly, the SE data came from different sources although for every single variable the same source was 
Table IV

Cervical screening and HPV vaccination policies in Latin America and the Caribbean Islands (LAC), 20 I I*

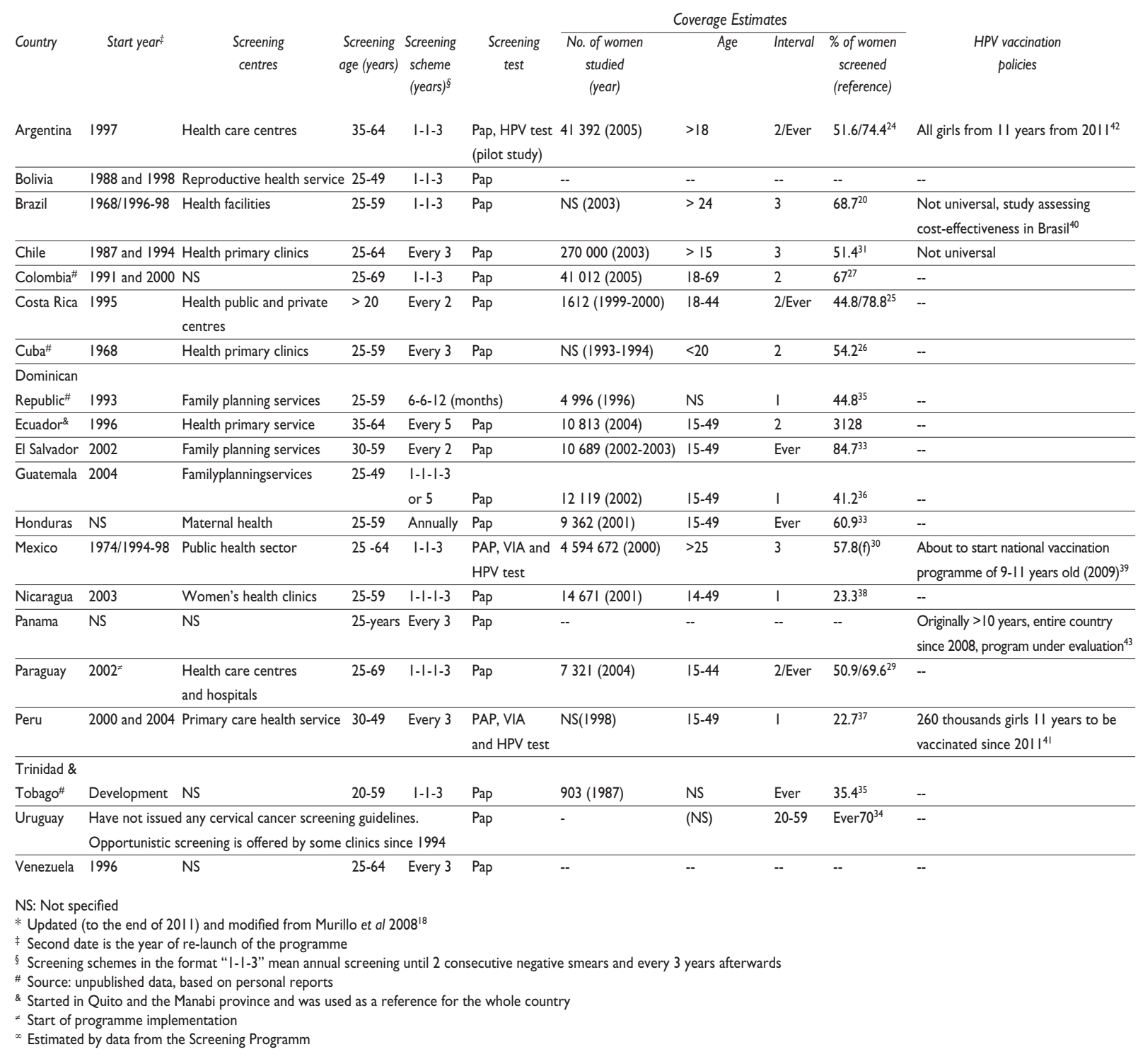

used for all 26 countries examined; reassuringly, the SE correlations with CC mortality were rather consistent despite the different quality of the data on the various SE indicators. Thirdly, HPV prevalence estimates, available for only 10 countries, were derived from local surveys using HCII or PCR methodology. The extent to which such surveys were nationally representative is unknown. Fourthly, data on screening activity and quality were scarce; national estimates of Pap-smear coverage were available only for a few countries based on different (non-comparable) methodologies. Finally, the findings relate to countries and cannot be extrapolated to an individual level.

In summary, CC mortality remains high in LAC. Our findings imply that improvements in the level of SE development of a country may reduce CC mortality even in the absence of organised screening programmes and HPV vaccination programmes.

Declaration of conflict of interests. The authors declare that they have no conflict of interests. 


\section{References}

I. Ferlay J, Shin HR, Bray F, Forman D, Mathers C, Parkin D. GLOBOCAN 2008: Cancer Incidence and Mortality Worldwide: IARC CancerBase No. 10 [Internet]. International Agency for Research on Cancer 2010. [cited September 2010] Available from: http://globocan.iarc.fr 2. Parkin DM, Whelan S, Ferlay J, Storm H. Cancer Incidence in Five Continents, Vol. I to VIII. Lyon: IARC scientific publication; 2002;vol. I to VIII:78.

3. Walboomers JM, Jacobs MV, Manos MM, Bosch FX, Kummer JA, Shah $\mathrm{KV}$, et al. Human papillomavirus is a necessary cause of invasive cervical cancer worldwide. J Pathol 1999;189(I):12-19.

4. de Sanjose S, Diaz M, Castellsague X, Clifford G, Bruni L, Munoz N, et al. Worldwide prevalence and genotype distribution of cervical human papillomavirus DNA in women with normal cytology: a meta-analysis. The Lancet infectious diseases 2007;7(7):453-459.

5. Anttila A, Ronco G, Clifford G, Bray F, Hakama M, Arbyn M, et al. Cervical cancer screening programmes and policies in 18 European countries. Br J Cancer 2004;91(5):935-94I.

6. Sankaranarayanan R, Budukh AM, Rajkumar R. Effective screening programmes for cervical cancer in low- and middle-income developing countries. Bull World Health Organ 200I;79(10):954-962.

7. Spadea T, D'Errico A, Demaria M, Faggiano F, Pasian S, Zanetti R, et al. Educational inequalities in cancer incidence in Turin, Italy. Eur J Cancer Prev 2009; 18(3):169-178.

8. Benard VB, Johnson CJ, Thompson TD, Roland KB, Lai SM, Cokkinides $V$, et al. Examining the association between socioeconomic status and potential human papillomavirus-associated cancers. Cancer 2008; I I3(I0 Suppl):2910-2918.

9. Ferlay J, Bray F, Pisani P, Parkin DM. GLOBOCAN 2002 Cancer Incidence, Mortality and Prevalence Worldwide. IARC CancerBase No 5 , 2004, version 2.0.

10. WHO. Core Health Indicators. [Accessed 20/0I/2007]; Available from: http://www3.who.int/whosis/core/core_select.cfm

II. PAHO. Regional Core Health Data Initiative. Table Generator System. [Accessed 20/0I/2007]; Available from: http://www.paho.org/English/ $\mathrm{SHA} /$ coredata/tabulator/newTabulator.htm

12. Organizacion Panamericana de Salud, Unidad de Análisis y Estadísticas de Salud (HA). Situación de Salud en las Américas: Indicadores Básicos 2006. Washington, D.C.: Organización Panamericana de la Salud; 2006. 13. Organización Panamericana de la Salud. Género, salud y desarrollo en las Americas: Indicadores Basicos 2005. Washington, D.C.: OPS, 2005. 14. United Nations Statistical Division. Statistical Databases. [Accessed 25/0 I/2007]; Available from: http://unstats.un.org/unsd/databases.htm 15. United Nations Development Programme. Human Development Report, 2006. New York City: UNDP, 2006.

16. WHO/ICO. Information Centre on HPV and Cervical Cancer (HPV Information Centre). [Accessed 20II I5 of July]; Available from: www. who.int/hpvcentre

17. Bruni L, Diaz M, Castellsague X, Ferrer E, Bosch FX, de Sanjose $S$. Cervical human papillomavirus prevalence in 5 continents: metaanalysis of I million women with normal cytological findings. J Infect Dis;202(I2): 1789- I799.

18. Murillo R, Almonte M, Pereira A, Ferrer E, Gamboa OA, Jeronimo J, et al. Cervical cancer screening programs in Latin America and the Caribbean. Vaccine 2008;26 Suppl I I:L37-48.

19. Ministerio de Salud Chile. Orientaciones para pesquisa y control del cáncer cervicouterino. Santiago: Minsal, 1998.

20. Martins L, Thuler L, Valente J. Coverage of the Pap smear in Brazil and its determining factors: a systematic literature review. [In Portuguese]. Rev Bras Ginecol Obstet 2005;27(8):485-492.
2I. d'Ottaviano-Morelli MG, Zeferino L, Cecatti JG, Terrabuio DR, Martinez EZ. Prevalence of cervical intraepithelial neoplasia and invasive carcinoma based on cytological screening in the region of Campinas, Sao Paulo, Brazil. Cad Saude Publica 2004;20(I):153-159.

22. Zeferino LC, Pinotti JA, Jorge JP, Westin MC, Tambascia JK, Montemor EB. Organization of cervical cancer screening in Campinas and surrounding region, Sao Paulo State, Brazil. Cad Saude Publica 2006;22(9):1909-1914.

23. MIDEPLAN. Encuesta CASEN. Santiago de Chile 2006.

24. Ministerio de Salud de la Nación. Encuesta Nacional de Factores de Riesgo 2005: Argentina. Instituto Nacional de Estadísticas y Censos de Argentina; 2006.

25. Chen M, Rosero L, Brenes G, León M, Gonzalez M, Vanegas J. Salud reproductiva y migración nicaragüense en Costa Rica 1999-2000: Resultados de una Encuesta Nacional de Salud Reproductiva. San José: Programa Centroamericano de Población (PCP) de la Escuela de Estadística e Instituto de Investigaciones en Salud (INISA), Universidad de Costa Rica; 200 I. 26. Fernandez-Garrote L, Lence-Anta J], Cabezas-Cruz E, Romero T, Camacho R. Evaluation of the cervical cancer control program in Cuba. Bull Pan Am Health Organ 1996;30(4):387-391.

27. Ojeda G, Ordóñez GM, Ochoa LH. Asociación Pro-Bienestar de la Familia Colombiana. Salud sexual y reproductiva: resultados encuesta nacional de demografía y salud, 2005. Bogota, Colombia: Asociación Probienestar de la Familia Colombiana, PROFAMILIA, 2005.

28. Centro de Estudios de Población y Paternidad Responsable (Ecuador), Centers for Disease Control (U.S.). Ecuador, ENDEMAIN-2004: informe preliminar. Quito, Ecuador [Atlanta, Georgia]: CEPAR; Centros para el Control de Enfermedades, 2005.

29. Centro Paraguayo de Estudios de Población. Centers for Disease Control and Prevention (U.S.), United States. Agency for International Development. Encuesta nacional de demografía y salud sexual y reproductiva 2004, ENDSSR 2004: informe resumido. Asunción, Paraguay: CEPEP, CDC, USAID, 2004

30. Subsecretaria de Prevención y Protección de la Salud. Programa de Acciín: Cáncer Cervicouterino. Mexico: Secretaría de Salud, 2002. 3I. MIDEPLAN. Encuesta CASEN. Santiago de Chile 2003.

32. Ministerio de Salud de la República Argentina. Subprograma de Deteccion Precoz de Cáncer de Cuello Uterino. In: Resolucion Ministerial $N^{\circ} 480 / 98$, Buenos Aires: Buenos Aires, 1998.

33. Monteith R, Stupp PW, McCracken SD, National Center for Chronic Disease Prevention and Health Promotion (U.S.). Division of Reproductive Health. Reproductive, maternal and child health in Central America: trends and challenges facing women and children: El Salvador, Guatemala, Hondouras, Nicaragua. Atlanta, GA: USAID, 2005.

34. Aguirre R, Bonino M, Espino A, Sapriza G. Programa Mujer y Género del Ministerio de Salud Pública. Diagnóstico de situación sobre género y salud en Uruguay. Washington: Panamerican Health Organization, 2006. 35. Lewis J. Analisis de la situacion del cancer cervicouterino en America Latina y el Caribe. Washington, D.C.: OPS, 2004.

36. Ministerio de Salud Pública de Guatemala. Encuesta Nacional de Salud Materno Infantil 2002 (Mujeres). Guatemala: Ministerio de Salud, 2002.

37. Instituto Nacional de Estadística e Informática (INEI) de Perú. Encuesta nacional de hogares. Perú: INEI, 1998.

38. Instituto Nacional de Estadísticas y Censos de Nicaragua. Encuesta Nicaragüense de Demografía y Salud. Nicaragua: INEI, $200 I$.

39. Hernández-Ávila M, Lazcano-Ponce E, Martínerz-Montañez O. Public Policies For HPV Screening and Vaccination in Mexico. 27th International Papillomavirus Conference and Clinical Workshop. Berlin, Germany September 17-22, 2011.

40. Instituto Nacional Cancer. Programa Nacional de Controle do Cancer do Colo do Utero: Prevencao. Brasil: INCA Ministerio da Saude;. 20II. [Accessed I0/I I/20I I]; Available from: http://wwwl.inca.gov.br/ conteudo_view.asp? id=327 
4l. Ministerio de Salud de Perú. Mas de 85 mil niñas de 10 años serán vacuandas contral el VPH en Lima y Callao. [Internet]. Perú;. 7 de Febrero 20I I. [Accessed 0I//2/20I I]; Available from: http://www.minsa.gob.pe/ portada/prensa/notas_auxiliar.asp?nota $=9915$

42. Ministerio de Salud, Presidencia de la Nación. Introducción de nuevas vacunas: vacuna contra el Virus Papiloma Humano (VPH)[Internet]. Buenos Aires: Republica Argentina; 15 de Agosto 20II. [Accessed 10/I I/2012]; Available from: http://www.msal.gov.ar/index.php/component/content/article/46//85-vph

43. Ostrander M. Panama first in region to provide free HPV vaccine to young adolescent girls [Internet] Panama: Unicef; 28 October [cited 20/I I/20I I]; Available from: http://www.unicef.org/infobycountry/ panama_46I69.html

44. Drain PK, Holmes KK, Hughes JP, Koutsky LA. Determinants of cervical cancer rates in developing countries. Int J Cancer 2002;100(2):199-205. 45. Eluf-Neto J, Nascimento CM. Cervical cancer in Latin America. Semin Oncol 200I;28(2):I88-97.

46. Schaap MM, Kunst AE. Monitoring of socio-economic inequalities in smoking: learning from the experiences of recent scientific studies. Public Health 2009; 123(2):103-109.

47. dos Santos Silva I, Beral V. Socioeconomic differences in reproductive behaviour. IARC Scientific Publications 1997(138):285-308.
48. Currin LG, Jack RH, Linklater KM, Mak V, Moller H, Davies EA. Inequalities in the incidence of cervical cancer in South East England 200I-2005: an investigation of population risk factors. BMC Public Health 2009;9:62.

49. Sankaranarayanan R. Royal Society of Tropical Medicine and Hygiene meeting at Manson House, London 17 January 2002. Cervical cancer in developing countries. Trans R Soc Trop Med Hyg 2002;96(6):580-585. 50. Parikh S, Brennan P, Boffetta P. Meta-analysis of social inequality and the risk of cervical cancer. Int J Cancer 2003;105(5):687-69I.

5I. Bermudez A. Can we do the same in the developing world? Gynecol Oncol 2005;99(3 Suppl I):S192-S196.

52. Hunter JL. Cervical cancer in lquitos, Peru: local realities to guide prevention planning. Cad Saude Publica 2004;20(I):160-17I.

53. Denny L, Quinn M, Sankaranarayanan R. Chapter 8: Screening for cervical cancer in developing countries. Vaccine 2006;24 Suppl 3:S7I-S77. 54. Mauad EC, Nicolau SM, Moreira LF, Haikel RL, Jr., Longatto-Filho $A, B a r a c a t E C$. Adherence to cervical and breast cancer programs is crucial to improving screening performance. Rural Remote Health 2009;9(3): I24I. 